\title{
Effect of Sweet Purple Potato (Ipomoea Batatas L.) Extract and Vitamin C on Endothelial Progenitor Cell Migration in Stable Coronary Disease Patient
}

\author{
Febryanti Hartono, Yudi Her Oktaviono, Dioko Soemantri
}

\begin{abstract}
Background : Number and function of Endothelial Progenitor Cells (EPC) are reduced in coronary artery disease (CAD) patient. EPC as progenitor of mature endothelial cell has important role for angiogenesis and neovasculogenesis. Dysfunctional EPC partly because of oxidative stress. Decreasing oxidative stress with antioxidant especially with sweet purple potato extract and vitamin as easily found in Indonesia, may improve EPC migration to ischemic organ in stable CAD patient. To analyze effect of sweet purple potato (Ipomoea batatas L.) extract and vitamin C on Endhotelial Progenitor Cell in Stable Coronary Disease patient.

Methods : This is experimental post-test control group study. Mononuclear cells (MNC) are isolated from peripheral blood of sample, and cultivated in medium for 3 days, immunofluorescence assay with CD34 as a marker for EPC. EPCs divided into sweet purple potato extract group ( $\mathrm{I}$ and $25 \mathrm{mcg} / \mathrm{mL}$ ), vitamin $C$ group ( 10 and $250 \mathrm{mcg} / \mathrm{mL}$ ) and control, incubated for 2 days. $5 \times 10^{5}$ cell taken from each group and place in upper chamber of Transwell system. EPC migration was assessed in lower chamber of Transwell system after 24 hours using automated cell counters. Statistic testing using ANOVA.

Results : EPC migration was increased significantly in sweet purple potato extract and vitamin C compared with control (3.03 \pm 0.01 , $2.15 \pm 0.03$ vs control I.2I $\pm 0.04, p<0.01)$. Increased dose of sweet purple potato extract and vitamin $C$ shows significantly increased of EPC migration ( I.8I \pm 0.02 vs $3.03 \pm 0.0 \mathrm{I}$ and $\mathrm{I} .47 \pm 0.04$ vs $2.15 \pm 0.03, \mathrm{p}<0.0 \mathrm{I})$. There is significantly differentiation between sweet potato purple extract and vitamin $C(3.03 \pm 0.0 \mathrm{I}$ vs $2.15 \pm 0.03, \mathrm{p}<0.0 \mathrm{I})$.

Conclusion : Sweet purple potato extract and vitamin C increased EPC migration dose-dependently. Sweet purple potato extract induces EPC migration better than vitamin C.
\end{abstract}

(Indonesian J Cardiol. 2019;40:326-331)

Keywords : EPC migration, Stable CAD, sweet purple potato extract, vitamin C, antioxidant

Department of Cardiology and Vascular Medicine, Faculty of Medicine, Airlangga University - Dr. Soetomo Hospital, Surabaya, Indonesia

\section{Correspondence:}

Febryanti Hartono, dr

Department of Cardiology and

Vascular Medicine, Faculty of

Medicine, Airlangga University

E-mail: febryantih@gmail.com

\section{Introduction}

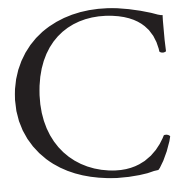
ardiovascular disease (CVD) is one of the biggest cause of deaths worldwide. About 17.7 millions people die because of CVD, 7.4 millions from it because of coronary artery disease (CAD). ${ }^{1}$ Pathophysiology of CAD is atherosclerosis. Atherosclerotic lesions are initiated from endothelial dysfunction, vascular inflammatory, 
oxidative stress, platelet aggregation and smooth muscle proliferation which develop CAD. ${ }^{2}$ Stable coronary artery disease is generally characterized by a disease causing exercise- and stress-related chest symptoms due to narrowing of $\geq 50 \%$ in the left main coronary artery and $\geq 70 \%$ in one or several of the major coronary arteries. ${ }^{3}$ Study of endothelial progenitor cell (EPC) by Asahara et al, shows that endothelium has the ability to repair itself and diferentiated into mature cells. ${ }^{4}$ Decreasing of EPC shown in stable CAD patients. Some of the mechanisms that can cause this include increased apoptosis of premature progenitor cells, increased oxidative stress that can cause cell death, and also interfere with signal pathways that regulate differentiation or migration EPC. 5 Experimental and clinical studies have shown there are various ways to increase circulating EPCs and improve their function. Cardiovascular pharmacotherapies have been shown to improve overall numbers and function of EPCs, such as statins, angiotensin converting enzyme (ACE) inhibitors, calcium channel blockers (CCBs). Neutricals as a endogen antioxidant and antiinflamation, such as flavonoid, curcumin, vitamin $\mathrm{C}$ and $\mathrm{E}$ work to protect edhothelial and inhibit atherosclerosis. ${ }^{6}$

Giving antioxidants is expected to improve EPC function such as migration. Anthocyanin in purple sweet potato (Ipomoea batatas L.) has antioxidant function as well as vitamin C. Administration of anthocyanin in endothelial cells in vitro can inhibit the production of proinflammatory interleukins. ${ }^{7}$ Ascorbic acid in vitamin $\mathrm{C}$ works to prevent low density protein (LDL) oxidation and inhibits endothelial and leukocyte cell interactions induced by cigarette smoke or oxidized LDL. ${ }^{8}$ Antioxidants derived from purple sweet potato and vitamin $\mathrm{C}$ have been studied to have an effect on increasing EPC proliferation, but their role in EPC migration is unknown, so that further research is needed. ${ }^{9}$

\section{Methods}

Blood samples were taken from patients with stable CAD which were men, 40-59 years old, had narrowing of $\geq 50 \%$ in the left main coronary artery and $\geq 70 \%$ in one or several of the major coronary arteries from angiography. Patients with history of acute myocardial infarction, acute limb ischemia, stent placement, coronary artery bypass grafting, diabetes mellitus, smoking, and anemia were excluded. Written informed consent was obtained from patients before peripheral blood sampling. The protocol was approved by local ethics committee.

\section{Isolated and Culture of EPC}

$40 \mathrm{ml}$ of blood was diluted with phosphate buffered saline (PBS) containing 2\% of fetal bovine serum (FBS). It was then centrifuged on Ficoll-Histopaque density gradients and interface mononuclear cells (MNCs) were collected. After two washes in PBS con- taining 2\% of FBS, the pellet were diluted with Stemline II Hematopoietic Stemcell Expansion Medium plus VEGF, and these cells were counted using hemocytometry. MNC with cell density $5 \times 10^{5}$ cells $/ \mathrm{ml}$ were plated on fibronectin coated 6-well plates. After three days, nonadherent cells were transferred into new well. Take some cell for immunofluorescence assay.

\section{Immunofuorescence Assay}

Cells were washed with PBS and xed with $3 \%$ formaldehyde for 15 minutes. Cells then added with $1 \%$ serum and washed again with PBS. Cells were stained with a FITC anti-CD34 antibody. Expression of the cells was documented with fluorescence microscope.

\section{Purple Sweet Potato (Ipomoea batatas L.) Ex- tract and Vitamin C}

After three day of cultured, EPCs divided into sweet purple potato extract group ( 1 and $25 \mathrm{mcg} / \mathrm{mL}$ ), vitamin C group (10 and $250 \mathrm{mcg} / \mathrm{mL}$ ) and control, incubated for 2 days.

\section{Migration Assay}

$5 \times 105$ cell taken from each group and place in upper chamber of Transwell system. EPC migration was assessed in lower chamber of Transwell system after 24 hours using automated cell counters.

\section{Statistical Analysis}

Data are expressed asmean \pm SD. To analyse differences, 
one-way ANOVA was used. Differences were considered significant if $\mathrm{p}$-values were $<0.01$. All statistical analyses were performed with SPSS for Windows.

\section{Results}

\section{Immunofuorescence Assay}

CD34 is one of the positive marker of EPC. Expression of CD34 was green under fluorescence microscope (Figure 1).

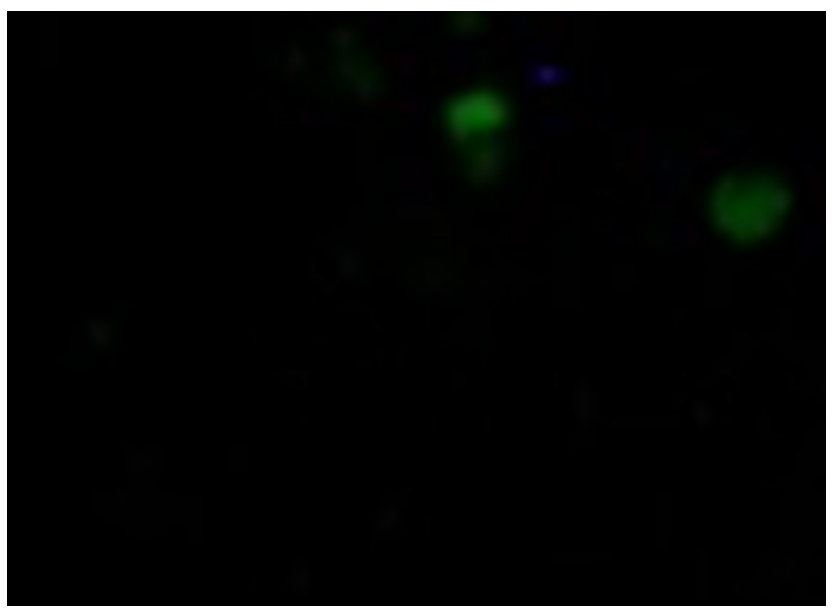

Figure 1. Immunofluorescence expression of CD34 marker

\section{Purple Sweet Potato (Ipomoea batatas L.) Ex- tract increase EPC Migration}

To investigate the effect of purple sweet potato (Ipomoea batatas L.) extract on EPC migration, we added two different dose of each group on EPC cultures. EPC migration was increased significantly in low dose (1 $\mathrm{mcg} / \mathrm{mL})$ and high dose $(25 \mathrm{mcg} / \mathrm{mL})$ sweet purple potato extract compared with control $(3.03 \pm 0.01$, $1.81 \pm 0.02$ vs control $1.21 \pm 0.04, \mathrm{p}<0.01)$. Increased dose of sweet purple potato extract shown significantly increased of EPC migration $(3.03 \pm 0.01$ vs $1.81 \pm 0.02$, $\mathrm{p}<0.01$ ) (Figure 2).

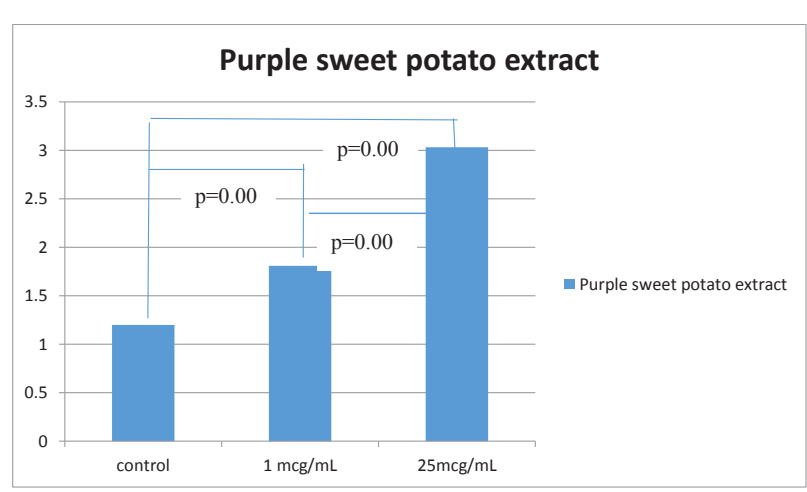

Figure 2. EPC migration with purple sweet potato extract

\section{Vitamin C increase EPC Migration}

EPC migration was increased significantly in low dose $(10 \mathrm{mcg} / \mathrm{mL})$ and high dose $(250 \mathrm{mcg} / \mathrm{mL})$ vitamin $\mathrm{C}$ compared with control $(2.15 \pm 0.03,1.47$ \pm 0.04 vs control $1.21 \pm 0.04, \mathrm{p}<0.01)$. Vitamin $\mathrm{C}$ shows significantly increased of EPC migration dose dependently $(2.15 \pm 0.03$ vs $1.47 \pm 0.04, \mathrm{p}<0.01)$. (Figure 3).

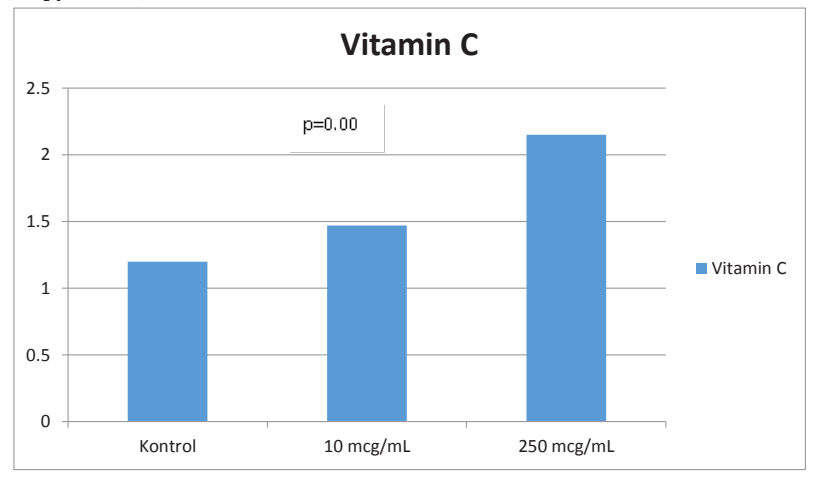

Figure 3. EPC migration with vitamin C

\section{Comparation Purple Sweet Potato (Ipomoea batatas L.) Extract with Vitamin $\mathrm{C}$ in EPC Migration}

EPC migration in low dose $(1 \mathrm{mcg} / \mathrm{mL})$ of purple sweet potato (Ipomoea batatas L.) extract shown increased significantly compare to low dose $(10 \mathrm{mcg} / \mathrm{mL})$ of vitamin $C(1.81 \pm 0.02$ vs $1.47 \pm 0.04, \mathrm{p}<0.01)$. Thus high dose $(25 \mathrm{mcg} / \mathrm{mL}$ ) of purple sweet potato (Ipomoea batatas L.) extract shown increased significantly compare to high dose $(250 \mathrm{mcg} / \mathrm{mL})$ of vitamin C $(3.03$ \pm 0.01 vs $2.15 \pm 0.03, \mathrm{p}<0.01$ ). (Table 1 ). These result 
Table 1. Comparison chart of EPC migration between groups of purple sweet potato extract with vitamin C in low and high doses.

\begin{tabular}{ccc}
\hline $\begin{array}{c}\text { Purple sweet potato group } \\
(\text { Mean } \pm \text { SD) }\end{array}$ & Vitamin C group & p-value \\
$1 \mathrm{mcg} / \mathrm{mL}(1.81 \pm 0.02)$ & $10 \mathrm{mcg} / \mathrm{mL}(1.47 \pm 0.04)$ & 0.000 \\
$25 \mathrm{mcg} / \mathrm{mL}(3.03 \pm 0.01)$ & $250 \mathrm{mcg} / \mathrm{mL}(2.15 \pm 0.03)$ & 0.000 \\
\hline
\end{tabular}

demonstrate that purple sweet potato extract increased EPC migration better than vitamin C (Figure 4).

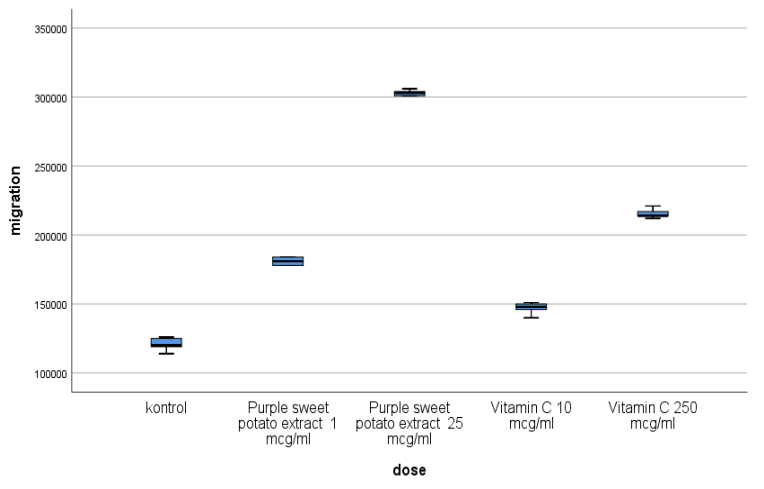

Figure 4. Comparison chart of EPC migration between groups of purple sweet potato extract with vitamin $\mathrm{C}$ in low and high doses.

\section{Discussions}

The result of these study demonstrate that purple sweet potato extract increase EPC migration in peripheral bood of stable CAD patient. Increase of EPC migration by purple sweet potato (Ipomoea batatas L.) extract is dose-dependent, the higher dose of purple sweet potato extract increase EPC migration. This result equal with previous study by Suastika et al, shows that purple sweet potato extract increase EPC proliferation. ${ }^{9}$ Addition of purple sweet potato extract which works as an exogenous antioxidant is useful in EPC protection against oxidative stress. The anthocyanin inside purple sweet potato is quite high compared to other foods, can help in reducing oxidative stress. ${ }^{10}$ In studies using anthocyanin containing chockberry extract which also originates from the flavanoid group, it was found that the migration process toward ischemic tissue was increased. The mechanism underlying this is still uncertain, from a study by Deshane et al in 2007 and Parzonko et al in 2015, a mechanism thought to originate from the activation of the $\mathrm{Pl} 3 \mathrm{~K} /$ Akt pathway by SDF1 which would affect the PKC and MAPK pathways and would activate $\mathrm{HO}-1$ resulting in an increase in EPC migration. This pathway can also underlie the occurrence of EPC migration to tissue that ischemia in the process of atherosclerosis. ${ }^{11,12}$

EPC migration was increase in the addition of vitamin $\mathrm{C}$ peripheral bood of stable $\mathrm{CAD}$ patient. This increase EPC migration in administration of vitamin $\mathrm{C}$ is also dose-dependent. Suastika et al stated that administration of vitamin $\mathrm{C}$ also increases EPC proliferation dose dependently. This shows that admition of vitamin $C$ increases number of EPC and repair EPC function in CAD patients. 9 Vitamin $\mathrm{C}$ as an antioxidant works to inhibit LDL oxidation and improve eNOS bonds which will increase the bioavailability of NO. NO formation will protect vascular endothelium. NO plays a role in relaxation of smooth muscle cells, peripheral vasodilation and prevents the effects of proinflammatory cytokines and adhesion molecules in the process of atherosclerosis. This also underlies the beneficial effects of vitamin C on EPC migration. ${ }^{13,14,15}$

In this study the administration of low dose $(1 \mathrm{mcg} /$ $\mathrm{mL}$ ) purple sweet potato extract gave a higher migration effect compare to low dose $(10 \mathrm{mcg} / \mathrm{mL})$ vitamin C. Likewise with the administration of high doses (25 $\mathrm{mcg} / \mathrm{mL}$ ) purple sweet potato extract increased EPC migration significantly compared with high dose (250 $\mathrm{mcg} / \mathrm{mL}$ ) vitamin C. This shows the administration of sweet potato extract purple is better in the EPC migration compared to vitamin $\mathrm{C}$. The differences in the mechanism of action and the antioxidant transduction pathway of these two groups are also thought to have an effect on EPC migration. Anthocyanin purple sweet potato extract is thought to work through the $\mathrm{Pl} 3 \mathrm{~K} /$ Akt pathway which will activate $\mathrm{HO}-1$ while vitamin $\mathrm{C}$ works as an electron donor to capture ROS which will activate eNOS to NO. ${ }^{11,12,13,14,15}$ 


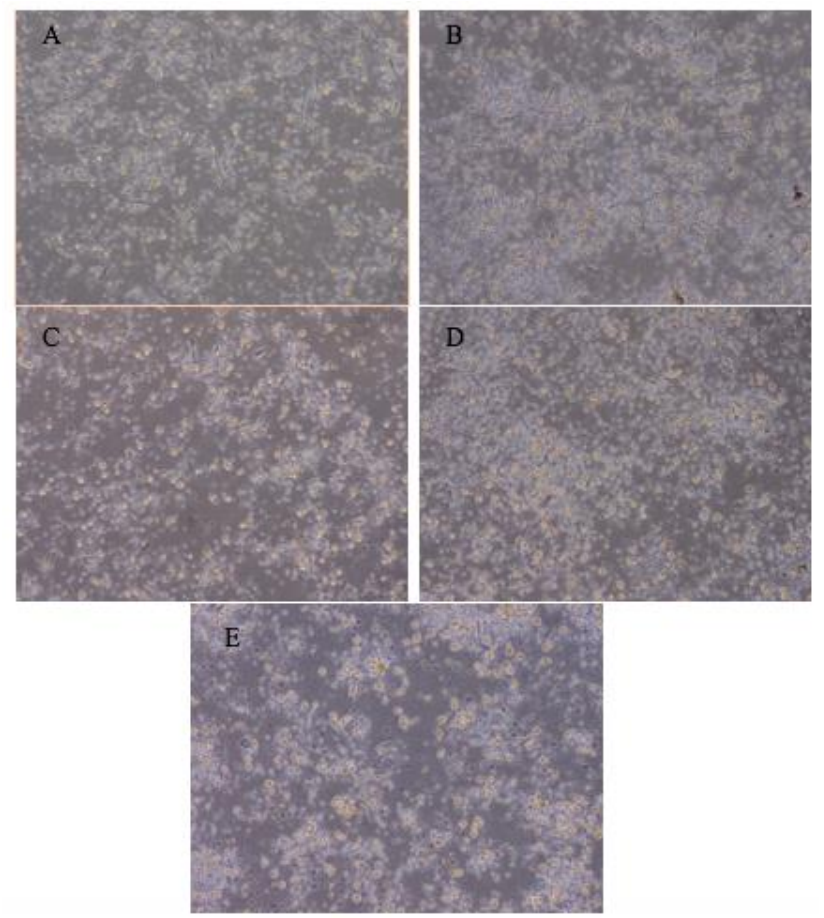

Figure 5. EPC that has migrated to the Transwell lower chamber: A. Group of purple sweet potato extract $1 \mathrm{mcg} /$ $\mathrm{mL}$; B. Group of purple sweet potato extract $25 \mathrm{mcg} / \mathrm{mL}$; C. Group of vitamin C $10 \mathrm{mcg} / \mathrm{mL}$; Group of vitamin C 250 $\mathrm{mcg} / \mathrm{mL}$; D. Controls group

\section{Conclusion}

The result of the present study define that purple sweet potato (Ipomoea batatas L.) extract increased EPC migration dose-dependently. Sweet purple potato (Ipomoea batatas L.) extract induces EPC migration better than vitamin $\mathrm{C}$ in stable $\mathrm{CAD}$ patient.

\section{Acknowledgments}

We would like to thank Community Service and Research Unit of Airlangga University for the grant support, Stem Cell Laboratory Institute of Tropical Disease Airlangga University for laboratory support, and Prof. Ferry Sandra. drg. PhD. CIPM for invaluable support.

\section{Ethical Clearance}

No. 0375/KEPK/VII/2018. from Research Ethics Committee, Dr. Soetomo Hospital, Surabaya.

\section{Publication Agreement}

The authors of this article give permission to Jurnal Kardiologi Indonesia (JKI) to publish this article in its journal if this article is accepted.

\section{Conflict of Interest}

The authors indicate no conflicts of interest.

\section{Funding}

Grant partially provided by Community Service and Research Unit, Airlangga University.

\section{List of Abbreviations}

ACE: angiotensin converting enzyme

CAD: coronary artery disease

CCB: calcium channel blocker

CVD: cardiovascular disease

eNOS: endothelial nitric oxide synthase

EPC: endothelial progenitor cell

FBS: phosphate buffered saline

HO-1: heme oxygenase-1

LDL: low density protein

MAPK: mitogen activated protein kinase

MNC: mononuclear cell

NO: nitric oxide

PBS: phosphate buffered saline

P13K: phosphatidylinositol-3 kinase

SD: standart deviation

\section{References}

1. WHO. 2017. Cardiovascular Diseases (CVDs) Fact Sheet. Access from: http://www.who.int/mediacentre/factsheets/fs317/en/ at 27 Desember 2017.

2. Siddique, A. 2010. Endothelial progenitor cells: what use for the cardiologist? J. Angiogenes. Res., 2:6.

3. Fadini GP, Agostini C, Sartore S, Avogaro A. 2007. Endothelial progenitor cells in the natural history of atherosclerosis. Atherosclerosis 194(1):46-54.

4. Asahara, T., Kawamoto, A. 2004. Endothelial progenitor cells for postnatal vasculogenesis. Am. J. Physiol. Cell. Physiol., 287, pp. C572-C579. 
5. Vasa, M., Fichtlscherer, S., Aicher, A., et al. 2001. Number and migratory activity of circulating endothelial progenitor cells inversely correlate with risk factors for coronary artery disease. Circ. Res., 89: e1e7.

6. Herring, T., Albrecht, J. 2005. Functional Foods. Extension Circular. University of Nebraska. Access from : www.reeis.usda.gov/web/crisprojectpages/0196754 at 23 Desember 2017.

7. Xia, M., Ling, W., Zhu, H., et al. 2007. Antochyanin prevents $\mathrm{CD} 40$-activated proinflammatory signaling in endothelial cells by regulating cholesterol distribution. Atheroscler. Thromb. Vasc. Biol., 27: 519-524.

8. Li, Y., Schellhorn, H. 2007. New developments and novel therapeutic perspectives for vitamin C. J. Nutr., 137: 2171-2184.

9. Suastika, Luh Olivia S., Oktaviono, Yudi H., Soemantri, Djoko; 2016. Efek pemberian ekstrak umbi ubijalar ungu (Ipomoea batatas L.) dan vitamin C terhadap proliferasi Endhotelial Progenitor Cells pada darah tepi penderita penyakit jantung koroner stabil. Universitas Airlangga. Surabaya

10. Spencer, J. 2010. Beyond antioxidants: the cellular and molecular interactions of flavonoids and how these underpin their actions on the brain. Proc. Nutr. Soc., 69 (2): 244-260.

11. Deshane, Jessy., et al. 2007. Stromal cell-derived factor 1 promotes angiogenesis via a heme oxygenase 1 - dependent mechanism. The Journal of Experimental Medicine. 204 (3): 605-618

12. Parzonko, A., Oswit, A., Bazylko, A., Naruszewicz, M. 2015. Anthocyans-rich Aronia melanocarpa extract possesses ability to protect endothelial progenitor cells against angiotensin II induced dysfunction. Phytomedicine, 22(14): 1238-1246.

13. Rixen, H., Kirkpatrick, C., Schmitz, U., Ruchatz, D., Mittermayer, C. 1989. Interaction between endothelial cells and basement membrane components. In vitro studies on endothelial cell adhesion to collagen types I, III, IV and high molecular weight fragments of IV. Exp. Cell Biol, 57: 315-323.

14. Cao, N., Liu, Z., Chen, Z., et al. 2012. Ascorbic acid enhances the cardiac differentiation of induced pluripotent stem cells through promoting the proliferation of cardiac progenitor cells. Cell. Res., 22: 219-236.
15. Trinidad, E., Gutiérrez, S., López, A., Orozco, M. 2013. Disease and therapy: a role for oxidants. In: J. Morales-Gonzales, ed., Oxidative Stress and Chronic Degenerative Diseases - A Role for Antioxidants. InTech. 